\title{
LITHOLOGIC AND GEOPHYSICAL LOGS OF DRILL HOLES FELDERHOFF FEDERAL 5-1 AND 25-1, AMARGOSA DESERT, NYE COUNTY, NEVADA
}

U.S. GEOLOGICAL SURVEY

Open-File Report 95-155

Prepared in cooperation with the NEVADA OPERATIONS OFFICE, U.S. DEPARTMENT OF ENERGY under Interagency Agreement DE-AI08-92NV10874

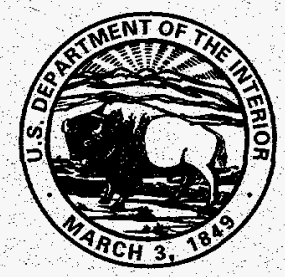




\title{
LITHOLOGIC AND GEOPHYSICAL LOGS OF DRILL HOLES FELDERHOFF FEDERAL 5-1 AND 25-1, AMARGOSA DESERT, NYE COUNTY, NEVADA
}

\author{
by W. J. CARR, J. A. GROW, U.S. Geological Survey, \\ Denver, Colorado;
}

and

S. M. KELLER, Science Applications International Corporation

Golden, Colorado

U.S. GEOLOGICAL SURVEY

Open-File Report 95-155

Prepared in cooperation with the

NEVADA OPERATIONS OFFICE,

U.S. DEPARTMENT OF ENERGY under

(Interagency Agreement DE-Al08-92NV10874)

\section{DISCLAIMER}

This report was prepared as an account of work sponsored by an agency of the United States Government. Neither the United States Government nor any agency thereof, nor any of their employees, makes any warranty, express or implied, or assumes any legal liability or responsibility for the accuracy, completeness, or usefulness of any information, apparatus, product, or process disclosed, or represents that its use would not infringe privately owned rights. Reference herein to any specific commercial product, process, or service by trade name, trademark, manufacturer, or otherwise does not necessarily constitute or imply its endorsement, recommendation, or favoring by the United States Government or any agency thereof. The views and opinions of authors expressed herein do not necessarily state or reflect those of the United States Government or any agency thereof. 


\section{U.S. DEPARTMENT OF THE INTERIOR BRUCE BABBITT, Secretary}

U.S. GEOLOGICAL SURVEY

Gordon P. Eaton, Director

The use of trade, product, industry, or firm names is for descriptive purposes only and does not imply endorsement by the U.S. Government.

For additional information write to: Chief, Earth Science Investigations Program

Yucca Mountain Project Branch U.S. Geological Survey Box 25046, MS 421 Denver Federal Center Denver, CO 80225
Copies of this report can be purchased from: U.S. Geological Survey Earth Science Information Center Open-File Reports Section Box 25286, MS 517 Denver Federal Center Denver, CO 80225 


\section{DISCLAIMER}

Portions of this document may be illegible in electronic image products. Images are produced from the best available original document. 


\section{CONTENTS}

Abstract

Introduction

Description of $\log$ data

Basalt.

Silicic volcanic units

Paleozoic rocks

Geophysical logs

Structural and possible hydrologic implications of $\log$ data

References

\section{FIGURES}

1. Location map of area around drill holes Felderhoff Federal 25-1 and 5-1

2. Geophysical logs of drill hole Felderhoff Federal 25-1

3. Geophysical logs of drill hole Felderhoff Federal 5-1

\section{TABLES}

1. Lithologic $\log$ and other data for drill hole Felderhoff Federal 25-1

2. Lithologic log and other data for drill hole Feiderhoff Federal 5-1

\section{CONVERSION FACTORS AND VERTICAL DATUM}

\begin{tabular}{rll} 
Multiply & By & To obtain \\
\hline & & \\
foot (ft) & 0.3048 & meter \\
inch (in.) & 25.4 & millimeter
\end{tabular}

Degree Celsius $\left({ }^{\circ} \mathrm{C}\right)$ may be converted to degree Fahrenheit $\left({ }^{\circ} \mathrm{F}\right)$ by using the following equation:

$$
{ }^{\circ} \mathrm{F}=9 / 5\left({ }^{\circ} \mathrm{C}\right)+32 \text {. }
$$

The following terms and abbreviations also are used in this report:

$$
\begin{aligned}
& \mathrm{g} / \mathrm{cm}^{3}=\text { grams per cubic centimeter } \\
& \text { ohmms }=\text { ohmmeters }
\end{aligned}
$$

Sea level: In this report "sea level" refers to the National Geodetic Vertical Datum of 1929 (NGVD of 1929)-a geodetic datum derived from a general adjustment of the first-order level nets of both the United States and Canada, formerly called Sea Level Datum of 1929. 


\title{
Lithologic and Geophysical Logs of Drill Holes Felderhoff Federal 5-1 and 25-1, Amargosa Desert, Nye County, Nevada
}

\author{
By W.J. Carr, S.M. Keller, and J.A. Grow
}

\section{Abstract}

Two wildcat oil and gas exploration holes drilled in 1991 on the northern edge of the Amargosa Desert penetrated Tertiary and Quaternary sedimentary rocks, alluvium, and basalt, possible Tertiary volcanic or volcaniclastic rocks, and Tertiary (?) and Paleozoic carbonate rocks. The easternmost of the two holes, Felderhoff-

Federal 5-1, encountered about 200 feet of alluvium, underlain by 305 feet of basalt breccia and basalt, about 345 feet of probable Tertiary tuffaceous sedimentary rocks, and 616 feet of dense limestone and dolomite of uncertain age. Drill hole $25-1$ penetrated 240 feet of alluvium and marl (?), and 250 feet of basalt breccia (?) and basalt, 270 feet of tuff (?) and/or tuffaceous sedimentary rocks, 360 feet of slide blocks (?) and large boulders of Paleozoic carbonate rocks, and 2,800 feet of Paleozoic limestone and dolomite.

The two drill holes are located within a northerly trending fault zone defined largely by geophysical data; this fault zone lies along the east side of a major rift containing many small basalt cruptive centers and, farther north, several caldera complexes. Drill hole 25-1 penetrated an inverted Paleozoic rock sequence; drill hole 5-1 encountered two large cavities 24 -inches wide or more in dense carbonate rock of uncertain, but probable Paleozoic age. These openings may be tectonic and controlled by a regional system of northeaststriking faults.

\section{INTRODUCTION}

The structural importance of the Amargosa Desert area, which is along the regional ground-water flow path from the Nevada Test Site (fig. 1), led to an interest in the geology, paleontology, and chronology of the rocks encountered by the two wildcat wells briefly described here. This report is intended to record the lithology and general stratigraphy in the drill holes, as determined by study and logging of the cuttings and interpretation of the geophysical logs. Other studies (Harris and others, 1992), particularly of the conodonts, indicated little potential for oil and gas in the Paleozoic rocks: cuttings from drill hole 25-1 show heating of the carbonate rocks to at least $300^{\circ} \mathrm{C}$. Carbonate rocks below $850 \mathrm{ft}$ in drill hole 5-1 were described as "thermally immature" (Harris and others, 1992); on this basis, and the absence of conodonts, they assigned these rocks to the Tertiary (Neogene?).

The authors thank Frank M. Byers, Jr., for his microscopic examination of thin sections of basalt cuttings handpicked from the two drill holes.

The holes were drilled by Transwestern Drilling, Inc., for Felderhoff Production Co. of Gainesville, Texas. Fclderhoff Federal 25-1 and 5-1 were drilled to depths of approximately 5,020 and 1,466 ft. Drill hole $25-1$ is located at latitude $36^{\circ} 37.1^{\prime} \mathrm{N}$., longitude $116^{\circ} 24.5^{\prime} \mathrm{W}$.; drill hole $5-1$ is located at approximately latitude $36^{\circ} 35.6^{\prime} \mathrm{N}$., longitude $116^{\circ} 23.1^{\prime} \mathrm{W}$., or about $2 \mathrm{mi} \mathrm{SSW}$, and $3.5 \mathrm{mi} \mathrm{SSE}$ of the town of Amargosa Valley, Nye County, Nevada (fig. 1). The cuttings were poor, contaminated, or not available for many intervals; hence, determination of lithology, particularly above the Paleozoic rocks, is difficult.

\section{DESCRIPTION OF LOG DATA}

Although this is primarily a data report, several observations and interpretations are made here that help place the drill holes in the context of regional geology.

\section{Basalt}

Both drill holes encountered basalt lava, and basalt breccia or pyroclastic material (tables 1 and 2 at the back of the report). The presence of basalt in 25-1 was predicted (Carr, 1984, fig. 14) from aeromagnetic data (Glen and Ponce, 1991), which show a very pro- 


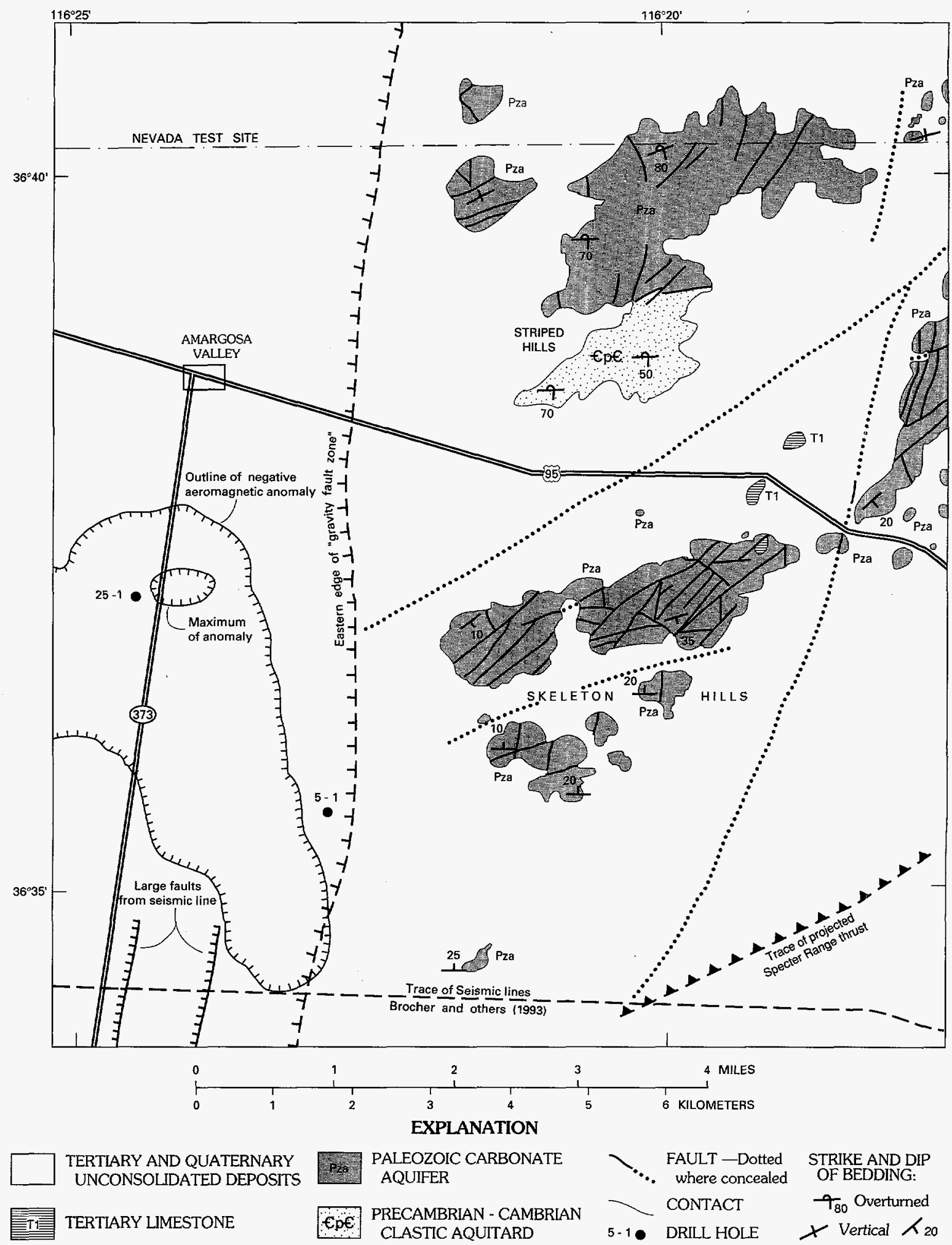

Figure 1. Map of area around drill holes Felderhoff Federal 25-1 and 5-1. 
nounced negative magnetic anomaly centered about $2,000 \mathrm{ft}$ east of the drill hole site (fig. 1). In drill hole 25-1, the top and bottom of basaltic material, determined mainly from gamma-ray logs (fig. 2), are at about 240 and $520 \mathrm{ft}$, respectively. Drill hole caving near the base of the basalt apparently yielded altered fragments that became obvious in the samples at about $1,850 \mathrm{ft}$ and continued down to total depth. A handpicked sample of these fragments was studied in an epoxy thin section by F.M. Byers, Jr. (U.S. Geological Survey, written commun., 1992), who described them as altered, porphyritic, pilotaxitic, microgranular basalt, similar to fragments picked from cuttings from drill hole 5-1. Iddingsite, calcite veinlets, and penninite (?) after clinopyroxene were noted. The caving presumably occurred around the bottom of the casing at about $500 \mathrm{ft}$, the latter depth suggested by geophysical logs (fig. 2) and the well completion report, as no samples were obtained between 330 and $545 \mathrm{ft}$.

Basalts in the drill holes are being dated by Brent D. Turrin (U.S. Geological Survey, oral commun., 1993), but results are not yet published. Basalts in drill holes nine miles east-southeast of drill hole 5-1 have been correlated chemically with basalts in the southern Nevada Test Site region dated at 8.5-11 Ma (Crowe and others, 1986).

The strength and roughly circular shape of the main part of the aeromagnetic anomaly near drill hole 25-1, and the shallow structural position of the buried basalt, suggest that at least part of the body is younger than the above-mentioned basalts in drill holes nine miles to the east. In other words, a basalt as old as $10 \mathrm{Ma}$ or so should be draped over or downdropped by the "gravity fault" system (Winograd and Thordarson, 1975; Brocher and others, 1993) which passes through the area of drill holes 25-1 and 5-1 (fig. 1). From the drill hole data (tables 1 and 2), the basalt lava is about the same thickness in both drill holes, and the top and base are at nearly the same elevation in both drill holes (25-1: 2,234 and 2,054 ft; 5-1: 2,236 and 2,036 ft). Even though the basalt in both drill holes is similar in depth, thickness, and petrography, the area near drill hole $5-1$ is outside the anomaly (fig. 1) and has much weaker magnetization than the area near drill hole 25-1. Thus, despite the apparent similarity of basalts from the two locations, the large difference in magnetic signature suggests important differences in the eruptive histories.

\section{Silicic Volcanic Units}

No definite intervals of silicic tuff were identified in the cuttings from these drill holes because of drill hole caving and the fact that the alluvium and other units above the Paleozoic rocks contain abundant volcanic clasts. Possible tuff intervals were noted from $615-760,1,300-1,480$, and 1,570-1,690 ft in drill hole $25-1$; the latter interval is judged most likely to be tuff, possibly the nonwelded tuff of the Timber Mountain Group (Byers and others, 1976), an important ashflow tuff in the region to the north. No definite tuff intervals were indicated by the cuttings from drill hole 5-1.

\section{Paleozoic Rocks}

On the basis of conodonts, Paleozoic rocks in drill hole 25-1 have been correlated with the Goodwin Limestone and possibly with the Nopah Formation (Harris and others, 1992). Color indices of conodonts from cuttings samples suggest heating of the rocks to at least $300^{\circ} \mathrm{C}$ (Harris and others, 1992), a common condition in southern Nye County. Proximity of the drill hole to the basalt eruptive center could account for some of the heating, but depth of burial is the most likely cause of the high thermal maturity. The interval in drill hole 25-1 from 2,200 to 3,300 ft did not yield conodonts, but those found between 3,300 and $5,000 \mathrm{ft}$ are of Early Ordovician age and indicate an inverted sequence (Harris and others, 1992). Overturned rocks equivalent to those found in the drill hole sequence crop out $4 \mathrm{mi}$ to the northeast in the Striped Hills (fig. 1).

In drill hole 5-1, no conodonts were found in the carbonate rocks, which were penetrated below about $850 \mathrm{ft}$. These rocks were assigned to the Neogene (?) (Harris and others, 1992), largely on the basis of thermally immature fish teeth found in the cuttings. Existing paleontologic information does not rule out the possibility that some or all of the carbonate rocks are Paleozoic. Middle Tertiary limestones of the region are generally at or near the Paleozoic surface and have been assigned to the Oligocene or lower Miocene by most workers (Sargent and others, 1970; Barnes and others, 1982; Cemen and others, 1985). The Tertiary limestones are not easily distinguished from Paleozoic, even in outcrop. In drill hole 5-1, cuttings samples are poor and contaminated, and there were several intervals of no circulation. The presence of dolomite in the lower $200 \mathrm{ft}$ of the drill hole (table 2) suggests that at least this part of the section is Palcozoic, as the senior author has not observed pervasive dolomite in Tertiary rocks of this area. It is possible that both Tertiary and Paleozoic carbonate rocks are present in drill hole 5-1. 
FEDERAL 25-1

DENS I TY

(G/CB)
FEDERAL 25-1

RESIST IVITY

(oma)

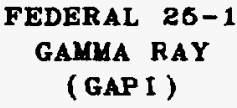

FEDERAL $26-1$

GAMMA RAY

(GAPI)

FEDERAL 25-1

CAL I PER

(IN)

DEP TH

$\begin{array}{llll}1.00 & 3.00 & 2.00 & 20000\end{array}$ $10 \quad 100 \quad 1000$
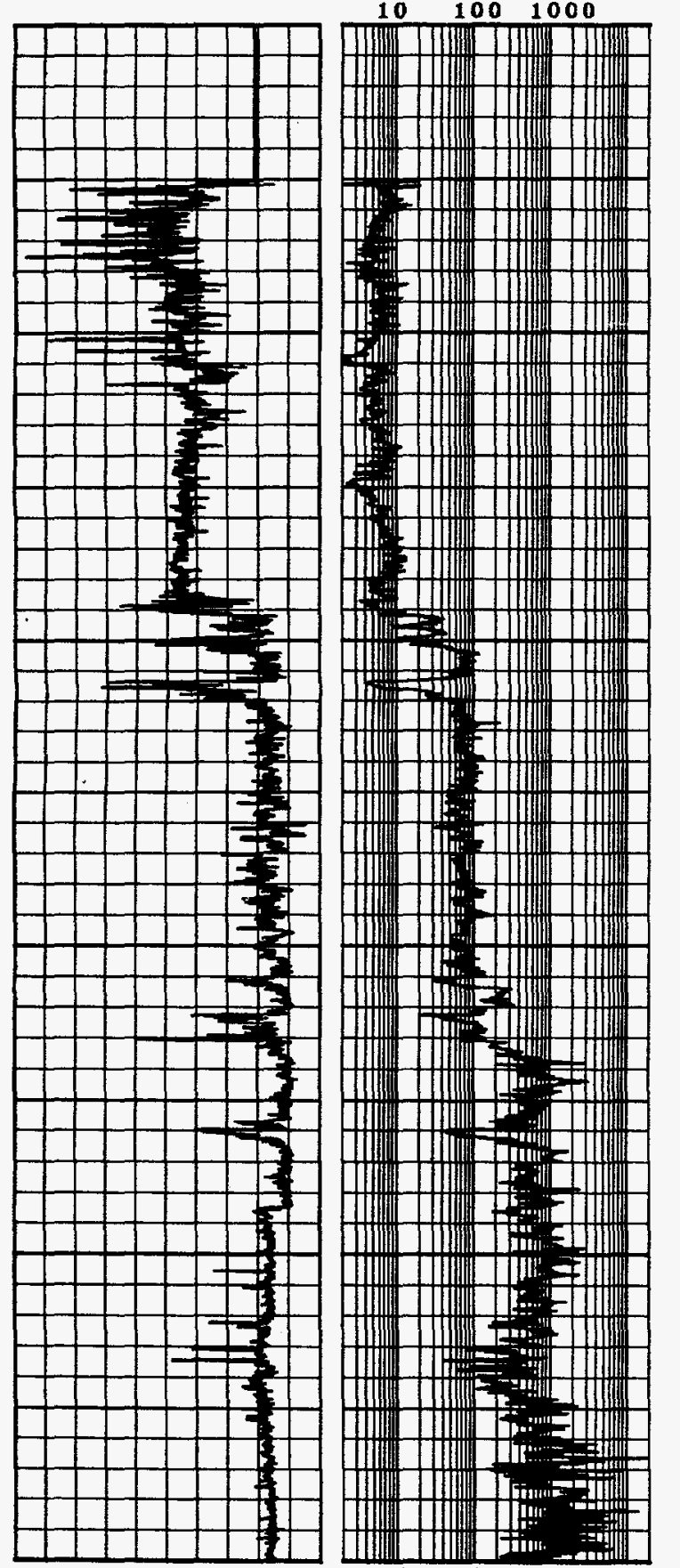

FEET

o

0

150

6.0

25.0
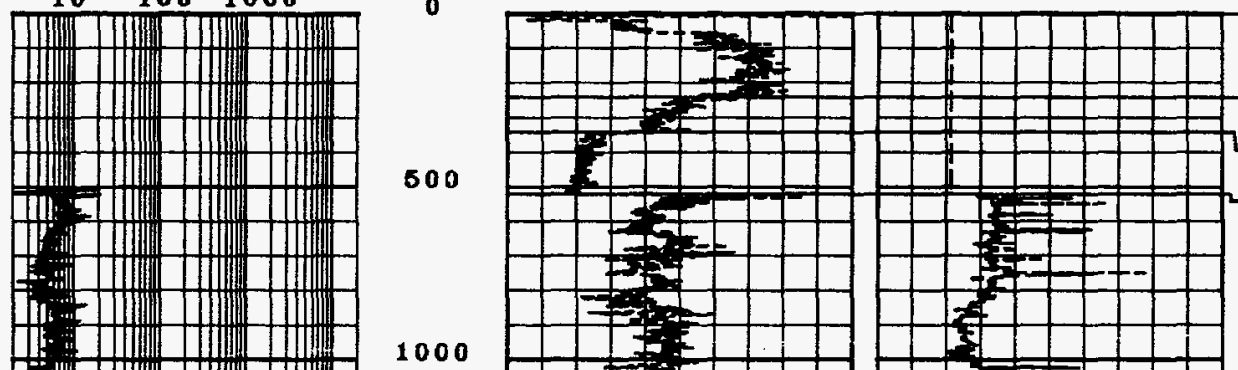

2000
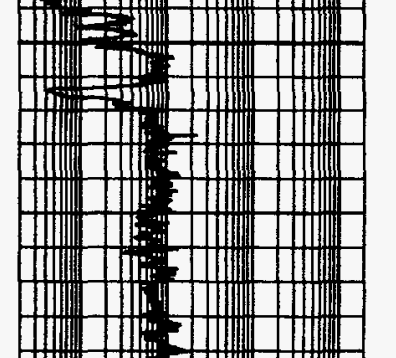

2500

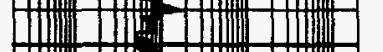

3000
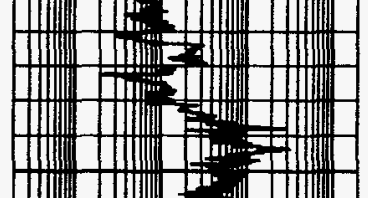

3500
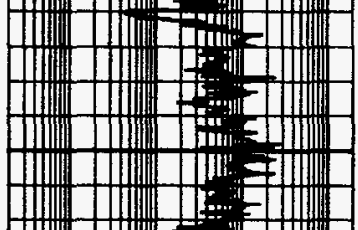

4000
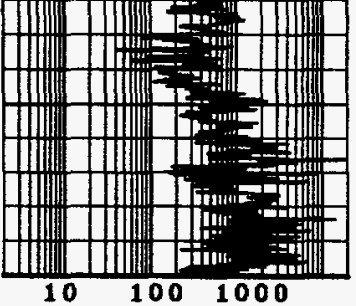

3.00

2.00

1

1000

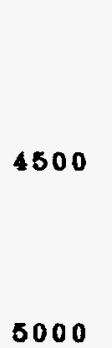

5000

\begin{tabular}{|}
\hline \\
\hline \\
\hline \\
\hline \\
\hline
\end{tabular}

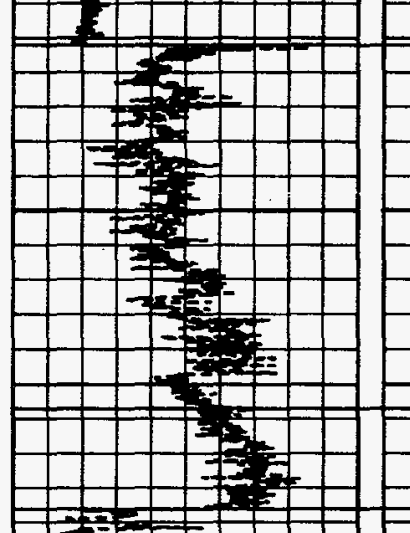

\begin{tabular}{|l}
\hline \\
\hline \\
\hline 3 \\
\hline 7 \\
\hline
\end{tabular}

3
5
5
3
5
5
3

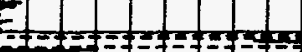
I

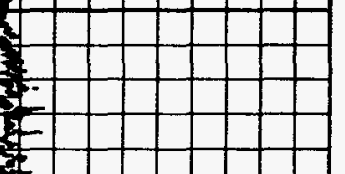

BAsartic ERTCCIA ?

BABAIT

G. AVLL.

TUPACHOU:

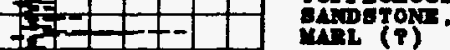

F

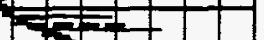

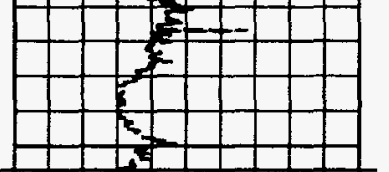

TUT $\triangle \mathrm{ND} / 0 \mathrm{~S}$

TUF्C.OU:

8L IDE BIOCLS AND Botuplas or

\section{DoLougre} II ANo Ton
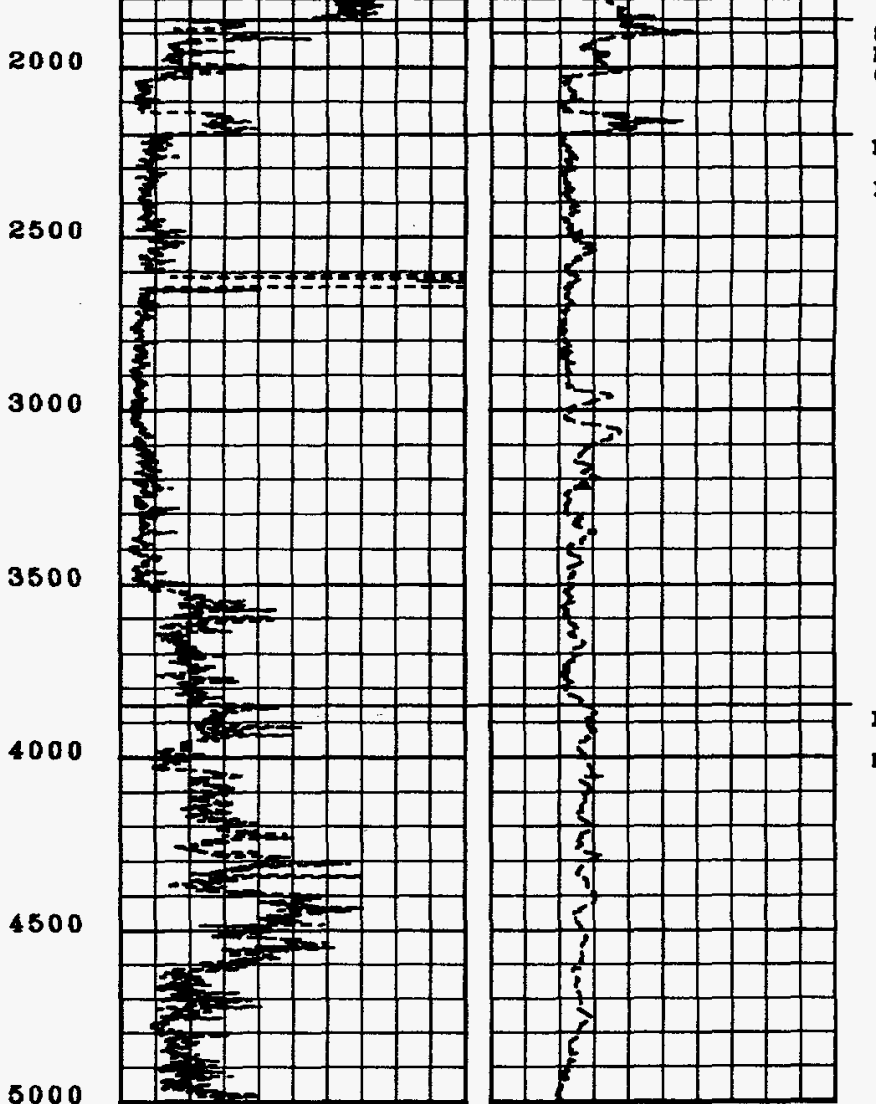

0

150

5.0

Irygarox: varoxing

Figure 2. Geophysical logs of drill hole Felderhoff Federal 25-1. 


\section{Geophysical Logs}

Density, resistivity, gamma ray, and caliper logs were run in drill holes 25-1 and 5-1 (figs. 2 and 3). Except for gamma-ray logs, which can be run through casing, the logs begin at $500 \mathrm{ft}$. The wells were cased to 519 and $504 \mathrm{ft}$, respectively. Below the casing, 8.75-in.-diameter drill bits were used. Analysis of the caliper logs shows that washouts with diameters in excess of 12 in. were common down to $2,200 \mathrm{ft}$ in drill hole $25-1$ and to $850 \mathrm{ft}$ in drill hole 5-1, where dense carbonate rocks were encountered. The washouts in the shallow part of these wells caused contamination problems at all deeper levels down to total depth. Washout zones and lost circulation problems occurred in both drill holes, but were most severe in drill hole 5-1.

The first 50 to $80 \mathrm{ft}$ in both wells have relatively low gamma-ray values (15-60 API units) and correlate with alluvium composed of heterogeneous volcanic and carbonate clasts identified in the cuttings (tables 1 and 2). From there down to about $200 \mathrm{ft}$, the gammaray values increase to $80-120$ API units and correlate with a coarsening and increasing percentage of volcanic clasts in the alluvium. The high gamma-ray values in this interval suggest the presence of radiogenic clays. Although clays were generally absent in the cuttings, they may have been washed away.

From 200 down to $340 \mathrm{ft}$, the gamma-ray values of the two wells drop to between 40 and 80 API units. Between 340 and $520 \mathrm{ft}$ depths, the gamma-ray values drop to about 30 API units. The latter zone correlates with basalt lava, which extends down to about $505 \mathrm{ft}$ in the 5-1 well and to $520 \mathrm{ft}$ in the 25-1 well. The gammaray pattern of the zone between 200 and $340 \mathrm{ft}$ appears more like the basalt lava than the overlying alluvium, suggesting a lithology of basaltic breccia or cinders.

Between the base of the basalt and the top of the dense carbonates, the densities average about $2.1 \mathrm{~g} / \mathrm{cm}^{3}$, the resistivities are low $(5-10 \mathrm{ohms})$, and the gamma-ray values are high (60-120 API units). These are Tertiary valley-fill deposits composed of a variety of tuffaceous clastic units with volcanic debris, Paleozoic debris, and possible lacustrine marls or spring deposits.

Alternating high and low density zones between 1,900 and $2,200 \mathrm{ft}$ in the $25-1$ well (fig. 2) are interpreted as slide blocks or megabreccias of Paleozoic (?) carbonates intercalated with the valley-fill deposits.

Below 2,200 $\mathrm{ft}$ in the 25-1 well, the densities are a relatively uniform $2.6-2.8 \mathrm{~g} / \mathrm{cm}^{3}$. Between 2,200 and $3,300 \mathrm{ft}$, the densities are $2.6-2.7 \mathrm{~g} / \mathrm{cm}^{3}$, the resistivity is intermediate (50-100 ohms), and the gamma-ray count is low ( 10 API units), suggesting relatively pure carbonate rock. From about 3,300 to $3,850 \mathrm{ft}$, density is the same or very slightly higher, and resistivity is higher but variable, between 300 and $1,100 \mathrm{ohm}$ meters. The gamma-ray log is also very slightly higher from 3,300 to $3,500 \mathrm{ft}$, but then increases abruptly at $3,500 \mathrm{ft}$ to values of 30 to about 100 API units. These geophysical $\log$ changes in the Paleozoic rocks do not appear to correlate well with observed variations in the cuttings. The higher resistivity of the section below $3,300 \mathrm{ft}$ seems to conflict with the higher gamma-ray count between 3,500 and $4,500 \mathrm{ft}$. The cuttings give no obvious indication of an increase in clays in this part of the section.

\section{STRUCTURAL AND POSSIBLE HYDROLOGIC IMPLICATIONS OF LOG DATA}

Drill holes 25-1 and 5-1 are located near the eastern margin of a regional asymmetric north-south structural trough named the Kawich-Greenwater rift (Carr, 1990). This 100-mile-long gravity low contains several caldera complexes and volcanic centers. In general, the east margin of the rift is characterized by a series of relatively small northerly striking faults stepping down to the west, whereas the west margin is more abrupt, consisting of a narrow zone of large faults down to the east. The structure on the east rift margin near drill holes 25-1 and 5-1 is referred to informally as the "gravity fault". Interpretation of geophysical data in the vicinity of drill holes 25-1 and 5-1 suggests (Brocher and others, 1993) that the "gravity fault" is a zone at least 1.5 -mi wide, and that the main displacement lies about 1 mile farther west than shown by Winograd and Thordarson $(1975, \mathrm{pl} .1)$. The data are from east-west seismic reflection and refraction lines (Brocher and others, 1993) located about $3.1 \mathrm{mi}$ south of drill hole 25-1 and 1.4 mi south of drill hole 5-1

(fig. 1), and from gravity (Healey and others, 1980) and resistivity (Greenhaus and Zablocki, 1982) data for the area. A west-dipping listric fault with more than $1,000 \mathrm{ft}$ of displacement is shown (Brocher and others, 1993, fig. 3) passing through the 25-1 drill hole, which is projected $3.2 \mathrm{mi}$ southward. A larger down-to-thewest fault, suggested by geophysical data, is shown (Brocher and others, 1993, fig. 3) about 0.5 mile farther west. Several smaller faults are suggested by the reflection profile in the area south of drill hole 5-1. Owing to the considerable distance between the seismic line and the drill holes, northward projection of specific faults to the drill hole area is problematical, although it is clear from the drill hole (figs. 2-5) and geophysical data (Brocher and others, 1993) that 
FEDERAL 5-1 RES IST IV I TY (OHMa)

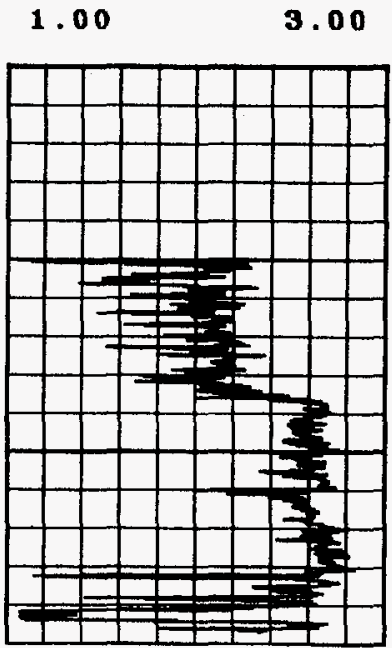

1.00

3.00

EDERAL 5-1

DENS I T Y

(G/C3)

$3.00 \quad 2.00 \quad 100 \quad 20000$

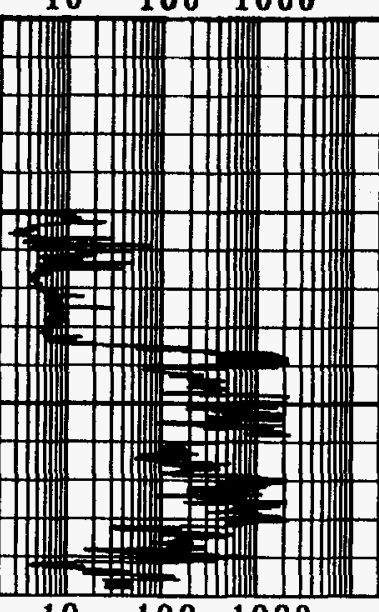

$10 \quad 100 \quad 1000$
FEDERAL $6-1$

GAMA RAY

(GAP I)

DEPTH

FEET

600

o

$\begin{array}{llll}0 & 150 & 5.0 & 25.0\end{array}$

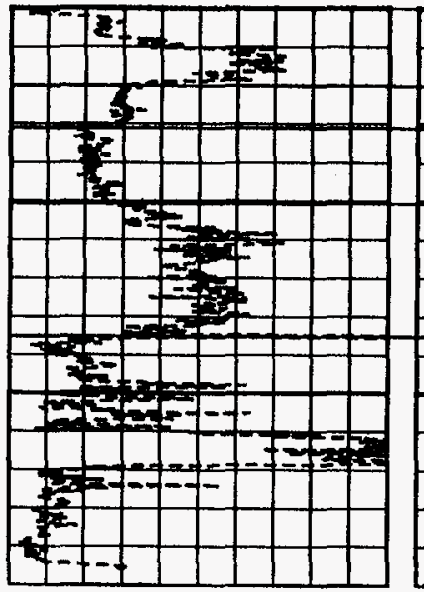

1500

0
FEDERAL 5-1

CAL I PER

(IN)

Figure 3. Geophysical logs of drill hole Felderhoff Federal 5-1. 
considerable prebasalt tectonic displacement of the Paleozoic surface occurs in the arca between the two drill holes.

The water table is shallow in the area of drill holes 25-1 and 5-1, lying at altitudes between about 2,300 and 2,360 $\mathrm{ft}$ (Winograd and Thordarson, 1975), or at depths of about 200 to $250 \mathrm{ft}$ (Oattield and Czarnecki, 1989), within the alluvium above the basalt. Paleozoic rocks (Ordovician Goodwin Limestone and possibly the Cambrian Nopah Formation) encountered by the 25-1 drill hole (Harris and others, 1992) belong to the "lower carbonate aquifer" of Winograd and Thordarson (1975), an important regional aquifer. In addition to having high fracture permeability, the carbonate rocks have tectonically enhanced permeability (Carr, 1984, 1987), especially in the region cast of the Kawich-Greenwater rift. On the basis of conodont stratigraphy, the Paleozoic rocks in drill hole 25-1 are believed to be overturned (Harris and others, 1992) like those in the nearby Striped Hills (fig. 1). Thrusts or reverse faults as a cause for the inverted stratigraphy cannot be ruled out. There does not appear to be stratigraphic continuity between the Striped Hills overturned section and that in drill hole 25-1 (fig. 1); the lower clastic confining units (Carrara Formation, Zabriskie Quartzite, Wood Canyon Formation, etc.) (Winograd and Thordarson, 1975) that forms the southern part of the Striped Hills does not continue on strike to drill hole 25-1. Offset on the "gravity" fault zone may be responsible for the mismatch.

Drill hole 5-1 lies (fig. 1) along the trend of a zone of predominantly northeast-striking faults mapped (Burchfiel, 1966) in the Skeleton Hills 2 mi to the northeast. The fault pattern is part of a 20 40 mile-wide regional system of northeast-striking faults called the Spotted Range-Mine Mountain zone (Carr, 1984, p. 56). Many of the seismically active and Quaternary displacement faults of the region lie within this zone (Carr, 1984, fig. 7). In areas such as Ash Meadows and Devils Hole, 10 to $15 \mathrm{mi}$ to the south and southeast of the Felderhoff drill holes, exposed tectonic openings (Carr, 1987; A.C. Riggs, U.S. Geological Survey, written commun., 1993) of northeast strike are commonly lined or filled with banded travertine veins (Carr, 1988; Pexton, 1984; Winograd and

Pearson, 1976). Large openings encountered by drill hole 5-1 in carbonate rock could not be plugged with lost circulation material and caused the drill hole to be abandoned considerably above its planned depth. The upper zone, as indicated by the caliper log (fig. 3), lies between about 1,310 and $1,330 \mathrm{ft}$ and is about 24 in. wide; the lower zone is at the bottom of the drill hole from about $1,400 \mathrm{ft}$ to $1,466 \mathrm{ft}$ and exceeds $25 \mathrm{in}$. in width. Samples were not recovered from either zone. Drill hole 5-1 provides clear evidence of sizeable openings in carbonate rock at a location that may be within a system of hydrologically transmissive structures. If the openings encountered in drill hole 5-1 are within the Paleozoic lower carbonate aquifer, and strike northeast as postulated, an effective transmissive path exists for southwestward movement of groundwater and possibly leakage into the late Tertiary and Quaternary deposits along the east side of the Kawich-Greenwater rift.

\section{REFERENCES}

Barnes, Harley, Ekren, E.B., Rogers, C.L., and Hedlund, D.C., 1982, Geologic and tectonic maps of the Mercury quadrangle, Nye and Clark Counties, Nevada: U.S. Geological Survey Miscellaneous Investigations Map I-1197, scale 1:24,000.

Brocher, T.M., Carr, M.D., Fox, K.F., Jr., and Hart, P.E., 1993, Seismic profiling across Tertiary extensional structures in the eastern Amargosa Desert, southern Nevada, Basin and Range province: Geological Society of America Bulletin, v. 105, p. 30-46.

Burchfiel, B.C., 1966, Reconnaissance geologic map of the Lathrop Wells 15-minute quadrangle, Nye County, Nevada: U.S. Geological Survey Miscellaneous Investigations Map I-474, scale 1:62,500.

Byers, F.M., Jr., Carr, W.J., Orkild, P.P., Quinlivan, W.D., and Sargent, K.A., 1976, Volcanic suites and related cauldrons of the Timber Mountain Oasis Valley caldera complex, southern Nevada: U.S. Geological Survey Professional Paper 919, 70 p.

Carr, W.J., 1984, Regional structural setting of Yucca Mountain, southwestern Nevada, and late Cenozoic rates of tectonic activity in part of the southwestern Great Basin, Nevada and California: U.S. Geological Survey Open-File Report 84-854, 109 p.

1987, Geology of the Devils Hole area, Nevada: U.S. Geological Survey Open-File Report 87-560, 32 p. 1990, Styles of extension in the Nevada Test Site region, southern Walker Lane Bel-An integration of volcano-tectonic and detachment fault models: Geological Society of America, Memoir 176, ch. 13, p. 283-303.

Cemen, I., Wright, L.A., Drake, R.E., and Johnson, F.C., 1985, Cenozoic sedimentation and sequence of deformational events at the southern end of the Furnace Creek strike-slip fault zone, Death Valley region, California, in Strike-slip deformation, basin formation, and sedimentation symposium: Society of Economic Paleontologists and Mineralogists, Special Publication 37, p. 127-141.

Crowe, B.M., Wohletz, K.H., Vaniman, D.T., Gladney, E., and Bower, N., 1986, Status of volcanic hazard studies 
for the Nevada nuclear waste storage investigations, vol. II: Los Alamos National Laboratories LA-9325-MS, $101 \mathrm{p}$.

Glen, J.M., and Ponce, D.A., 1991, Aeromagnetic map of the Beatty $30^{\circ} \times 60^{\circ}$ quadrangle, Nevada and California: U.S. Geological Survey Open-File Map 91-105, scale $1: 100,000$.

Greenhaus, M.R., and Zablocki, C..., 1982, A Schlumberger resistivity survey of the Amargosa Desert, southern Nevada: U.S. Geological Survey Open-File Report $82-897,151 \mathrm{p}$.

Harris, A.G., Repetski, J.E., Clayton, J.L., Grow, J.A., Carr, M.D., and Daws, T.A., 1992, Results from wildcat wells near Yucca Mountain, Nevada: Geological Society of America Abstracts with Programs, Rocky Mountain Section, v. 24, n. 6, p. 17.

Healey, D.L., Wahl, R.R., and Oliver, H.W., 1980, Bouguer gravity map of Nevada, Death Valley sheet: Nevada Bureau of Mines and Geology Map 69, scale 1:250,000.

Oatfield, W.J., and Czarnecki, J.B., 1989, Hydrologic inferences from drillers logs and resistivity surveys in the
Amargosa Desert, southern Nevada: U.S. Geological Survey Open-File Report 89-234, p. 296.

Pexton, R.E., 1984, Geology and paleohydrology of part of the Amargosa Desert in Nevada: University of Nevada, Reno, unpublished thesis, $63 \mathrm{p}$.

Sargent, K.A., McKay, E.J., and Burchfiel, B.C., 1970, Geologic map of the Striped Hills quadrangle, Nye County, Nevada: U.S. Geological Survey Geologic Quadrangle Map GQ-882, scale 1:24,000.

Winograd, 1.J., and Pearson, F.J., Jr., 1976, Major carbon-14 anomaly in a regional carbonate aquifer-Possible evidence for mega-scale channeling, south-central Great Basin: Water Resources Research, v. 12, n. 6, p. 1125-1143.

Winograd, 1.J., and Thordarson, W., 1975, Hydrogeologic and hydrochemical framework, south-central Great Basin, Nevada-California, with special reference to the Nevada Test Site: U.S. Geological Survey Professional Paper 712-C, $126 \mathrm{p}$. 


\section{TABLE 1. LITHOLOGIC LOG AND OTHER DATA FOR DRILL HOLE FELDERHOFF FEDERAL 25-1}

LOCATION: $1,845 \mathrm{ft}$ from south line, 1,980 ft from east line, NW 1/4, SE 1/4, Sec. 25, T. 15S., R. 49E, Nye County, Nevada

ALTITUDE: $2,574 \mathrm{ft}$

HOLE DIAMETER: 36 in. $0-50 \mathrm{ft} ; 121 / 4$ in. $50-569 \mathrm{ft} ; 83 / 4$ in. to $5,020 \mathrm{ft}$

TOTAL DEPTH: $5,020 \mathrm{ft}$

COMPLETION: October 8, 1991

CASING: 20 in. conductor to $50 \mathrm{ft} ; 95 / 8$ in. conductor $50-519 \mathrm{ft}$; uncased 519 to $5,020 \mathrm{ft}$ (T.D.)

DRILLED BY: Transwestern Drilling, Inc., for Felderhoff Production Co., Gainesville, Texas

LITHOLOGY LOGGED BY: W.J. Carr, January 13-16, 1992, from microscopic examination of cuttings samples. Some contacts and lithology derived in part from geophysical logs.

\section{Depth interval \\ below land surface}

(feet)

\section{Lithology}

0-38 No samples.

38-131 Alluvium, consisting almost entirely of volcanic rock clasts, many coated with calcium carbonate. Clay coatings increase downward.

131-240 Alluvium, coarse, probably bouldery. Nearly all volcanic clasts. Very little carbonate coating or clay remain in cuttings, but high gamma-ray log values (fig. 2) suggest presence of clay or marl beds.

240-340 Cuttings similar to 131-240 ft, except a few basaltic fragments appear at about $290 \mathrm{ft}$. No samples from $310-340 \mathrm{ft}$. Gamma-ray geophysical log (fig. 2) suggests this interval is at least partly basaltic breccia.

340-490 Basalt, dark gray to dark reddish brown, with olivine phenocrysts, largely altered to iddingsite. Cuttings are at least $75 \%$ basalt.

490-520 Lost circulation material. Fibrous wood and plastic fragments. Geophysical logs suggest base of basalt at about $520 \mathrm{ft}$. Casing set to $520 \mathrm{ft}$.

520-540 Alluvium, light purplish gray to tan, tuffaceous. Fragments variable in lithology, but all are volcanic, and mostly tuff. A few basalt fragments.

540-600 Alluvium or tuffaceous sediment, light purplish gray to tan. Fragments variable in lithology as in $520-540 \mathrm{ft}$, but quartz and biotite grains are more abundant. Grains thinly coated with clay and carbonate.

600-615 No samples. 


\begin{tabular}{|c|c|}
\hline $\begin{array}{l}\text { Depth interval } \\
\text { below land surface } \\
\text { (feet) }\end{array}$ & Lithology \\
\hline $615-760$ & $\begin{array}{l}\text { Tuffaceous sandstone or tuff (?), light gray to tan, mostly } 1-3 \mathrm{~mm} \text { tuff and mineral } \\
\text { grains, including prominent quartz, some cuhedral. Calcium-carbonate coatings. } \\
\text { Lost circulation material present. Carbonate increases downward. Biotite common. } \\
\text { Soft, very light gray, highly calcareous material (cement?) as dried lumps in cuttings; } \\
\text { lumps commonly contain small fibers and occasional pieces of orange and blue } \\
\text { plastic. }\end{array}$ \\
\hline $760-820$ & $\begin{array}{l}\text { Lost circulation material. Largely lost circulation material (wood fibers and plastic) } \\
\text { and soft, very light gray calcareous siltstone (?) or ground-up cement. }\end{array}$ \\
\hline $820-850$ & $\begin{array}{l}\text { Marl or fine-grained lacustrine(?) limestone. About } 30 \% \text { calcium carbonate, tan to } \\
\text { light pinkish gray; } 40 \% \text { mineral and rock grains mostly }<2 \mathrm{~mm} \text {; and siltstone (?) } \\
\text { similar to } 760-820 \mathrm{ft} \text {. A fragment of Paleozoic quartzite noted in } 835-850 \mathrm{ft} \\
(254.5-259.1 \mathrm{~m}) \text { sample. }\end{array}$ \\
\hline $850-1,030$ & $\begin{array}{l}\text { Volcanic rock and mineral grains. Largely volcanic and mineral rock grains, nearly } \\
\text { all }<1 \mathrm{~mm} \text {. Quartz and feldspar prominent, together with white to light pink } \\
\text { carbonate grains, which decrease downward; nearly all grains are rounded and } \\
\text { frosted, especially in lower part of interval. }\end{array}$ \\
\hline $1,030-1,250$ & $\begin{array}{l}\text { Volcanic sandstone (?). Mineral and volcanic rock grains mostly }<0.5 \mathrm{~mm} \text {. Quartz, } \\
\text { feldspar, minor biotite, mostly frosted and rounded, } 60 \% \text {; remainder is rounded } \\
\text { volcanic rock fragments. None to very little carbonate cement. Magnetite and } \\
\text { hornblende present. Probably a volcanic sandstone, well sorted, very poorly } \\
\text { indurated, fine grained. Magnetite grains increase downward. }\end{array}$ \\
\hline $1,250-1,300$ & $\begin{array}{l}\text { Sandstone (?), light gray to tan, fine- to coarse-grained, calcareous. Most clasts are } \\
\text { volcanic rock, } 1-5 \mathrm{~mm} \text {; minor }(<20 \%) \text { mineral grains, mostly quartz and feldspar. } \\
\text { Rock fragments are angular to subrounded. }\end{array}$ \\
\hline $1,300-1,480$ & $\begin{array}{l}\text { Sandstone or tuff (?). Similar to } 1,250-1,300 \mathrm{ft} \text {, except for abundant fragments of } \\
\text { white to pink nonwelded ash-flow tuff. Phenocrysts of biotite, quartz, and feldspar. } \\
\text { Possibly Rainier Mesa Tuff, Timber Mountain Group (Tmr). Fragments mostly } \\
\text { subangular to angular. }\end{array}$ \\
\hline $1,480-1,510$ & $\begin{array}{l}\text { Sandstone (?). Samples are fine-grained sandstone clasts, mostly well rounded, and } \\
\text { frosted volcanic rock and mineral grains averaging } 0.5 \mathrm{~mm} \text { diameter. A few } \\
\text { (about } 5 \% \text { ) grains of calcium carbonate. }\end{array}$ \\
\hline $1,510-1,570$ & Gravel. Clasts same as above, but mostly $1-5 \mathrm{~mm}$ \\
\hline $1,570-1,690$ & $\begin{array}{l}\text { Tuff (?), light gray to light pinkish brown, nonwelded, contaminated with a variety of } \\
\text { volcanic rock fragments. Montmorillonite clay present. Phenocrysts are mostly } \\
\text { quartz, feldspar, and biotite. (The main reason to suspect this might be tuff and not } \\
\text { alluvium or sediment is that there is a subtle increase in consistency and size of } \\
\text { fragments.) Quartz is distinctly bipyramidal. This interval is another candidate for } \\
\text { Timber Mountain Group. }\end{array}$ \\
\hline $1,690-1,780$ & Sandstone (?) and gravel (?). Heterogeneous cuttings, similar to $1,480-1,570 \mathrm{ft}$. \\
\hline $1,780-1,840$ & $\begin{array}{l}\text { Gravel. Mostly volcanic rock fragments averaging about } 2 \mathrm{~mm} \text {, but a few gray } \\
\text { Paleozoic carbonate rock fragments. }\end{array}$ \\
\hline
\end{tabular}




\section{Depth interval \\ below land surface \\ (feet)}

$1,840-1,990$

$1,990-2,000$

$2,000-2,150$

$2,150-2,200$

$2,200-2,360$

$2,360-2,490$

$2,490-2,630$

$2,630-2,700$

$2,700-2,820$

$2,820-2,870$

$2,870-2,900$

$2,900-2,960$

2,960-3,050

$3,050-3,140$

$3,140-3,170$

\section{Lithology}

Gravel, Paleozoic blocks, and basalt. Same as $1,780-1,840 \mathrm{ft}$, except about $5 \%$ of fragments are Paleozoic, and increase downward. At $1,930 \mathrm{ft}$, fragments are about $50 \%$ Paleozoic, mostly gray dolomite and limestone, but occasional quartzite fragments are present. Density and resistivity logs show great variation in the interval $1,840-2,150 \mathrm{ft}$, suggesting large boulders or blocks of Paleozoic rocks intercalated with volcanic debris. Gray Paleozoic carbonate is about $75 \%$ of sample at $2,030 \mathrm{ft}$.

At about $1,850 \mathrm{ft}(563.9 \mathrm{~m})$ is the first appearance of a trachytic mafic volcanic rock that is found as caving fragments throughout the remainder of the drill hole. The fragments appear to be from an altered basalt with plagioclase, clinopyroxene, and olivine phenocrysts; plagioclase is largely altered to calcite and clay, clinopyroxene to chlorite, and olivine to iddingsite. Breccia and/or pyroclastic material in some fragments. Very similar to basalt in cuttings in Felderhoff Federal 5-1 at about $300-500 \mathrm{ft}$ (91.4-152.4 m).

No samples.

Gravel and Paleozoic blocks. Continuation of unit 1,840-1,990 ft. Cuttings and geophysical logs suggest a large mass of carbonate rocks, possibly Bonanza King Formation, from about 2,020-2,120 ft (615.7-646.2 m).

Gravel (?) or Paleozoic rock debris (?). Contains about 50\% volcanic and 50\% Paleozoic carbonate rock fragments. Geophysical logs suggest the upper contact of this unit is closer to $2,120 \mathrm{ft}$ than $2,150 \mathrm{ft}$.

Limestone and dolomitic limestone. Top of Paleozoic. Light to dark gray. Zones of white to pink calcite veins (?). Fragments average about $1 \mathrm{~mm}$. Trachytic basalt fragments notable here and in many succeeding samples are presumably cavings from higher in hole.

Limestone and calcite, pink to gray, cuttings very fine $(<1 \mathrm{~mm})$. Much of lightcolored material is siliceous.

Dolomite and limestone, light gray to white, tan and pink, somewhat siliceous. Many fragments below $2,540 \mathrm{ft}$ are reddish color. Resistivity log shows some lower resistivity (clayey) zones in the interval $2,500-2,620 \mathrm{ft}$. Intervals of irregular gammaray $\log$ spikes between $2,600-2,650 \mathrm{ft}$.

Dolomite and limestone, gray to red-brown, with much orange-pink siliceous material, which is translucent on thin edges and has tiny white opaque spots that could be altered feldspar. Might be a quartz siltstone or silicification in a fault zone.

Dolomite and minor limestone, gray to very light gray, with about $10 \%$ fragments of the orange-pink siliceous material mentioned in interval $2,630-2,700 \mathrm{ft}$.

Limestone and subordinate dolomite, light gray to very light gray; dolomite increases downward.

Dolomite and subordinate limestone, gray to light gray.

Limestone and subordinate dolomite, light gray to gray.

Dolomite and limestone, gray to pink; slight alteration (?) or silty carbonate layers (?).

Dolomite and minor limestone, gray to dark gray.

Dolomite, gray to light gray, with minor iron staining and silicification. 


\begin{tabular}{|c|c|}
\hline $\begin{array}{l}\text { Depth interval } \\
\text { below land surface } \\
\text { (feet) }\end{array}$ & Lithology \\
\hline $3,170-3,340$ & $\begin{array}{l}\text { Limestone and dolomite, gray to light gray; slight iron staining } 3,620-3,340 \mathrm{ft} \text {. } \\
\text { Cuttings contaminated. }\end{array}$ \\
\hline $3,340-3,350$ & Contaminated cuttings. More than half are Tertiary rock fragments. \\
\hline $3,350-3,380$ & No samples. Caving; fishing operation. \\
\hline $3,380-3,420$ & Contaminated cuttings. More than half are Tertiary rock fragments. \\
\hline $3,420-3,625$ & $\begin{array}{l}\text { Dolomite and minor limestone, gray to dark gray. White calcite veins sporadically } \\
\text { present. Rock is more coarsely crystalline than overlying section. Cuttings are } \\
\text { better and larger. }\end{array}$ \\
\hline $3,625-3,650$ & $\begin{array}{l}\text { Limestone and dolomite, gray to dark gray, very fine grained. Probably interbedded } \\
\text { with dolomite like } 3,420-3,625 \mathrm{ft} \text {. }\end{array}$ \\
\hline $3,650-3,860$ & Dolomite, dark gray, coarse grained, with calcite veins. \\
\hline $3,860-3,950$ & $\begin{array}{l}\text { Dolomite, gray to light gray, very fine to medium grained. Occasional pyrite. } \\
\text { Corresponds to break to slightly lower density on neutron log. Slickensides noted on } \\
\text { a fragment in } 3,900-3,925 \text {-ft sample, and at other places down hole. }\end{array}$ \\
\hline $3,950-4,320$ & $\begin{array}{l}\text { Limestone and minor dolomite, gray to light gray, fine grained. Occasional pyrite. } \\
\text { Cuttings throughout the limestone unit tend to be flatter chips, suggesting thinner } \\
\text { bedding. }\end{array}$ \\
\hline $4,320-4,610$ & Limestone. Similar to $3,950-4,320 \mathrm{ft}$, except with some medium-grained zones. \\
\hline $4,610-5,000$ & $\begin{array}{l}\text { Limestone and subordinate dolomite, gray to light gray, fine to medium grained, } \\
\text { becoming finer grained downward, but coarser again below about } 4,950 \mathrm{ft} \text {, finer near } \\
\text { bottom. }\end{array}$ \\
\hline $5,000-5,020$ & No samples. \\
\hline
\end{tabular}




\section{TABLE 2. LITHOLOGIC LOG AND OTHER DATA FOR DRILL HOLE FELDERHOFF FEDERAL 5-1}

LOCATION: $1,980 \mathrm{ft}$ from north line, $660 \mathrm{ft}$ from west line, SW 1/4, NW 1/4, Sec. 5, T. 16S., R. 50E, Nye County, Nevada

ALTITUDE: $2,536 \mathrm{ft}$

HOLE DIAMETER: 36 in. 0-60 ft; $121 / 4$ in. $60-504 \mathrm{ft} ; 83 / 4$ in. to $504-1,466 \mathrm{ft}$ (T.D.)

TOTAL DEPTH: $1,466 \mathrm{ft}$

COMPLETION: October 25, 1991

CASING: 20 in. conductor to $60 \mathrm{ft} ; 95 / 8 \mathrm{in}$. conductor to $504 \mathrm{ft}$; uncased 504-1,466 ft

DRILLED BY: Transwestern Drilling, Inc., for Felderhoff Production Co., Gainesville, Texas

LITHOLOGY LOGGED BY: W.J. Carr, January 21-22, 1992, from microscopic examination of cuttings samples. Some contacts and lithology derived in part from geophysical logs.

\section{Depth interval \\ below land surface}

(feet)

\section{Lithology}

$0-60$

$60-200$

$200-270$

$270-300$

$300-330$

$330-505$

$505-545$

$545-640$

$640-850$

$850-1,000$
No samples.

Alluvium, consisting of heterogeneous volcanic rocks, and a few Paleozoic carbonate rock fragments. Cuttings coarsen downward.

Alluvium, marl (?), and basalt breccia. Cuttings are nearly all volcanic clasts and quartz, feldspar, and biotite; mostly pebble-sized clasts 240-270 ft. Gamma-ray log (fig. 4) suggests this interval is at least partly basaltic breccia.

Volcanic breccia, basaltic, light brown to gray-brown, partly cemented by calcite; plagioclase and olivine are largely altered to calcite and iron oxide.

Basalt, gray to dark gray, mostly fine equigranular; relatively fresh, including olivine.

No samples, but well completion report and geophysical logs indicate this interval is basalt.

No samples.

Siltstone and calcareous claystone, very light yellow to light gray. Siltstone silicified.

Cavings include basalt, tuff, cement, and lost circulation material; latter two components increase downward.

Lost circulation material, cement, and clay or gel. A few fragments of silicified and slightly calcareous light-colored tuff. Texture of the latter is shard-like. Cement and lost circulation material increase downward, until nearly $100 \%$ in lower half of interval. Samples unrepresentative of formation.

Limestone. Top of Tertiary (?) or Paleozoic (?) limestone. Sample is similar to $640-850 \mathrm{ft}$, except gray to light gray fragments of Paleozoic carbonate rock begin to be evident; these are mostly finely crystalline limestone. Geophysical logs show increase in density and resistivity and decrease in hole size at about $850 \mathrm{ft}(259.1 \mathrm{~m})$. Most fragments are very light gray, fine grained, uniform, and could be Tertiary carbonate. Pyrite noted. 


\section{Depth interval \\ below land surface}

(feet)

\begin{tabular}{|c|c|}
\hline $1,000-1,220$ & $\begin{array}{l}\text { Limestone, gray to light gray, most fragments are medium crystalline, and many } \\
\text { have calcite veinlets or spots. Occasional fragments with slickensides (?). Lithology } \\
\text { uniform, but color darkens downward to dark gray and rock becomes more } \\
\text { dolomitic. }\end{array}$ \\
\hline $1,220-1,260$ & Limestone, dolomitic, gray, medium grained. \\
\hline $1,260-1,310$ & Dolomite and minor limestone, gray, medium crystalline. \\
\hline $1,310-1,330$ & $\begin{array}{l}\text { Lost circulation material. Wood fibers and a few gray dolomite fragments. Caliper } \\
\log \text { indicates large void } 1,320-1,330 \mathrm{ft}(402.3-405.4 \mathrm{~m}) \text {, more than } 20 \text { in. across. } \\
\text { Probable fault. }\end{array}$ \\
\hline $1,330-1,340$ & Dolomite, gray, medium crystalline. \\
\hline $1,340-1,370$ & $\begin{array}{l}\text { Dolomite, very light gray to gray, medium crystalline, with minor brownish-gray } \\
\text { calcareous siltstone (?). Fragments of calcite and iron-stained siliceous material. } \\
\text { Fault zone (?). }\end{array}$ \\
\hline $1,370-1,466$ & $\begin{array}{l}\text { No samples. Lost circulation zone. Caliper log indicates large openings } \\
1,410-1,445 \mathrm{ft}(429.8-440.4 \mathrm{~m}) \text { and at } 1,462 \mathrm{ft}(445.6 \mathrm{~m}) \text {. Openings exceed } 24 \mathrm{in} \text {. } \\
\text { Probable major fault zone. }\end{array}$ \\
\hline
\end{tabular}

